\title{
Effects of temperature and salt concentration on latent Edwardsiella ictaluri infections in channel catfish
}

\author{
John A. Plumb, Craig Shoemaker \\ Southeastern Cooperative Fish Disease Project, Department of Fisheries and Allied Aquacultures \\ and
}

Alabama Agricultural Experiment Station, Auburn University, Alabama 36849, USA

\begin{abstract}
Juvenile channel catfish Ictalurus punctatus, $10 \%$ of which had a natural, latent infection of Edwardsiella ictaluri, were held in water at $15 \pm 2^{\circ} \mathrm{C}$. Following elevation of the water temperature to $25^{\circ} \mathrm{C}$ for $28 \mathrm{~d}, 77 \%$ died with clinical E. ictaluri infections. This level of mortality was significantly higher $(\mathrm{p}<0.05)$ than mortality attributable to E. ictaluri when the water temperature was raised to $18^{\circ} \mathrm{C}(10 \%)$ or to $30^{\circ} \mathrm{C}(23 \%)$. Channel catfish naturally infected with E. ictaluri were exposed to 0,100 , 1000,2000 , and $3000 \mathrm{mg} \mathrm{l}^{-1} \mathrm{NaCl}$ at $25^{\circ} \mathrm{C}$ for $28 \mathrm{~d}$. Mortalities of channel catfish held in $\mathrm{NaCl}$ concentrations of 0 and $100 \mathrm{mg} \mathrm{l}^{-1}(100 \%$ and $96 \%$ respectively) were significantly higher than those held in $\mathrm{NaCl}$ concentrations of 1000,2000 , and $3000 \mathrm{mg} \mathrm{l}^{-1}(33,43$, and $17 \%$, respectively).
\end{abstract}

KEY WORDS: Channel catfish $\cdot$ Bacteria $\cdot$ Salt $\cdot$ Temperature $\cdot$ Edwardsiella ictaluri

\section{INTRODUCTION}

Edwardsiella ictaluri, the etiological agent of enteric septicemia of catfish (ESC), is one of the most serious bacterial diseases of farmed channel catfish Ictalurus punctatus. Since the first detection of E. ictaluri by Hawke (1979), and its subsequent description (Hawke et al. 1981), the pathogen has been found throughout much of the geographical area where channel catfish are cultured. E. ictaluri infections are most prevalent and most severe at water temperatures between 20 and $28^{\circ} \mathrm{C}$ (Francis-Floyd et al. 1987, Plumb 1988). However, recently ESC has occurred more frequently in the warm summer months and during the winter than previously reported. As epizootiological data accumulate on this pathogenic bacterium, it is being found in more diverse fish species and aquacultural environments. E. ictaluri has been confined to infections in freshwater fish species, however, an exception may be its presence in sea bass Dicentrarchus labrax (Blanch et al. 1990).

Some artesian well waters in western Alabama, USA, contain as much as $2500 \mathrm{mg} \mathrm{l}^{-1}$ of chloride (equivalent to about $4200 \mathrm{mg} \mathrm{l}^{-1} \mathrm{NaCl}$ ). Where these high salinity waters have been used in channel catfish culture ponds, Edwardsiella ictaluri infections seldom or never occur (G. Whitis, Fish Farming Center, Greensboro, AL, pers. comm.). As a result of these observations it has been proposed that large quantities of $\mathrm{NaCl}$ be added to freshwater channel catfish culture ponds as a method for preventing ESC where $E$. ictaluri is enzootic. Although $\mathrm{NaCl}$ has long been used therapeutically and prophylactically in cultured fish (Herwig 1979, Wellborn 1985), the effect of high salt concentrations on channel catfish infected with $E$. ictaluri has not been evaluated in the laboratory. The objectives of this study were to determine the effects of temperature and the effects of elevated salt concentration on a population of channel catfish with a naturally acquired, latent infection of $E$. ictaluri.

\section{MATERIALS AND METHODS}

Juvenile channel catfish ( 7 to 8 mo old), with a mean weight of $7.4 \mathrm{~g}$ and average total length of $10.5 \mathrm{~cm}$, and 
held in $15 \pm 2^{\circ} \mathrm{C}$ water with $<20 \mathrm{mg} \mathrm{l}^{-1} \mathrm{NaCl}$, were used in the experiments. Based on the occurrence of an occasional moribund individual showing minimal clinical signs of ESC, it was known that this particular lot of fish was latently infected with Edwardsiella ictaluri. The fish were treated with $167 \mathrm{mg} \mathrm{l}^{-1}$ formalin for $1 \mathrm{~h}$ to eliminate external parasites (Epistylis sp. and Trichodina sp.) and with a $1 \mathrm{~h}$ exposure to $20 \mathrm{mg} \mathrm{l}^{-1}$ of nitrofurazone on 3 consecutive days to eliminate a chronic Flexibacter columnaris infection $1 \mathrm{wk}$ before the initial laboratory studies. To establish the background prevalence of E. ictaluri infection in these fish, 10 fish were killed with $100 \mathrm{mg} \mathrm{l}^{-1}$ of tricaine methanesulfonate (MS-222) and samples of their kidneys were streaked on E. ictaluri isolation medium (EIM) and incubated at $30^{\circ} \mathrm{C}$ (Shotts \& Waltman 1990). Moribund and freshly dead fish were removed daily throughout the following 2 studies and similarly necropsied for bacterial infections. Isolated bacteria were identified on the basis of their biochemical characteristics (Shotts \& Bullock 1975, Hawke et al. 1981, Austin \& Austin 1987).

Experiments were carried out in static 57 l glass aquaria filled with 401 of well water that had a total hardness and alkalinity of $40 \mathrm{mg} \mathrm{l}^{-1}$ of $\mathrm{CaCO}_{3}$. Temperature was regulated with submersible aquarium heaters, and aeration was supplied with compressed air through air stones. Each aquarium was stocked with 10 fish in all replicates of all experiments. Each treatment was in triplicate with the exception of the temperature study involving fish held at $18^{\circ} \mathrm{C}$; this treatment was in duplicate. At the end of each experiment the surviving fish were killed with MS-222, necropsied for bacterial infections, and buried.

To evaluate the effect of water temperature on the transition of Edwardsiella ictaluri from a latent stage to clinical infection, triplicate groups of channel catfish were held at $18 \pm 1,25 \pm 1$, and $30 \pm 1^{\circ} \mathrm{C}$ for $28 \mathrm{~d}$. Because water was static, $100 \mathrm{mg} \mathrm{l}^{-1}$ of $\mathrm{NaCl}$ was maintained to prevent methemoglobinemia (brown blood disease); however, nitrite levels were not measured (Tomasso et al. 1979). Fifty percent of the water was replaced at $5 \mathrm{~d}$ intervals and approximately $100 \mathrm{mg}^{-1}$ of $\mathrm{NaCl}$ was maintained.

The effect of $\mathrm{NaCl}$ on the transition of latent Edwardsiella ictaluri infection to a clinical infection was determined by exposing triplicate groups of fish to $0,100,1000,2000$, and $3000 \mathrm{mg} \mathrm{l}^{-1}$ of technical grade $\mathrm{NaCl}$ (American Chemical Society certified) on a continuous basis for $28 \mathrm{~d}$. Latently $E$. ictaluri infected fish were moved from the $15^{\circ} \mathrm{C}$ holding tank to aquaria with freshwater, the appropriate quantity of $\mathrm{NaCl}$ was added to establish the desired concentration, and the water temperature was gradually increased to $25 \pm$ $1{ }^{\circ} \mathrm{C}$. Approximately $50 \%$ of the water in each aquar- ium was replaced every $5 \mathrm{~d}$ and the desired salt concentration restored. At $24 \mathrm{~h}$ and $28 \mathrm{~d}$ after adding $\mathrm{NaCl}$, water samples of the different treatments were analyzed for chloride ion concentration (Boyd 1979). Total mortality data from each treatment in each experiment were analyzed by 1 -way analysis of variance using the general linear models procedure (GLM) to compare arcsine-transformed percent mortalities (SAS Institute 1985).

\section{RESULTS AND DISCUSSION}

A $10 \%$ Edwardsiella ictaluri carrier rate in the channel catfish population was recorded prior to the temperature and $\mathrm{NaCl}$ concentration experiments. Our data confirmed that $E$. ictaluri is most serious in cultured channel catfish when water temperatures are near $25^{\circ} \mathrm{C}$, where a cumulative morlality of $77 \%$ due to E. ictaluri infection occurred over $28 \mathrm{~d}$ (Table 1). This mortality was significantly higher $(p<0.05)$ than $E$. ictaluri induced mortality of fish maintained at $18^{\circ} \mathrm{C}$ $(10 \%)$ or in the fish held at $30^{\circ} \mathrm{C}(23 \%)$. However, cumulative total mortality attributable to all causes was $93 \%$ for fish held at $25^{\circ} \mathrm{C}$, and $50 \%$ and $58 \%$, respectively, for groups held at $18^{\circ} \mathrm{C}$ and $30^{\circ} \mathrm{C}$; these mortalities were not significantly different from each other ( $p>0.05$ ) (Table 1). The lack of significance between total mortalities at the different temperatures may have been due to the presence of other bacterial etiologies (Table 2), or because there were only 2 replicates in the $18^{\circ} \mathrm{C}$ tests rather than 3 , thus resulting in a Type II statistical error (Wise et al. 1993).

Only 1 of 24 bacterial isolates from fish in $25^{\circ} \mathrm{C}$ water was not Edwardsiella ictaluri (Table 2). However, only 2 of 9 bacterial isolates from the fish held at $18^{\circ} \mathrm{C}$ were E. ictaluri while 9 of the 18 isolates from the fish held at $30^{\circ} \mathrm{C}$ were E. ictaluri. These data further emphasize the importance of temperature in the epizootiology of

Table 1. Ictalurus punctatus infected with Edwardsiella ictaluri. Effects of temperature on mortality (values given as \%) in latently infected channel catfish held at various temperatures for $28 \mathrm{~d}$. Fish were held in $15^{\circ} \mathrm{C}$ water before the start of the experiments. Mortality values with different letters are significantly $(p<0.05)$ different from others in the same row

\begin{tabular}{|lccc|}
\hline & $18^{\circ} \mathrm{C}$ & $25^{\circ} \mathrm{C}$ & $30^{\circ} \mathrm{C}$ \\
\hline No. fish stocked & 20 & 30 & 30 \\
$\begin{array}{l}\text { Mortality } \\
\quad \text { Total }\end{array}$ & $50^{\mathrm{a}}$ & $93^{\mathrm{a}}$ & $58^{\mathrm{a}}$ \\
$\quad \begin{array}{l}\text { Due to E. ictaluri } \\
\text { Day of first E. ictaluri } \\
\text { caused death }\end{array}$ & $10^{\mathrm{a}}$ & $77^{\mathrm{b}}$ & $23^{\mathrm{a}}$ \\
\hline
\end{tabular}


Table 2. Ictalurus punctatus infected with Edwardsiella ictaluri. Bacteria isolated from latently infected channel catfish held at 3 different temperatures and necropsied over $28 \mathrm{~d}$. Fish were held in $15^{\circ} \mathrm{C}$ water before the start of the experiment. M-D: moribund or freshly dead fish necropsied during study period (some fish had dual infections); $T$ fish (survivors) necropsied at the end of the experiment (some fish had dual infections)

\begin{tabular}{|lcccccc|}
\hline & \multicolumn{2}{c}{$18^{\circ} \mathrm{C}$} & \multicolumn{2}{c}{$25^{\circ} \mathrm{C}$} & \multicolumn{2}{c|}{$30^{\circ} \mathrm{C}$} \\
& $\mathrm{M}-\mathrm{D}$ & $\mathrm{T}$ & $\mathrm{M}-\mathrm{D}$ & $\mathrm{T}$ & $\mathrm{M}-\mathrm{D}$ & $\mathrm{T}$ \\
\hline No. of fish necropsied & 10 & 10 & 28 & 2 & 17 & 13 \\
Bacterial species isolated & & & & & & \\
$\quad$ E. ictaluri & 1 & 1 & 23 & 0 & 7 & 2 \\
Aeromonas sp. & 1 & 0 & 1 & 0 & 6 & 1 \\
Pseudomonas sp. & 0 & 0 & 0 & 0 & 0 & 1 \\
Streptococcus sp. & 5 & 0 & 0 & 0 & 0 & 1 \\
$\quad$ Flexibacter columnaris & 0 & 1 & 0 & 0 & 0 & 0 \\
$\quad$ None & 4 & 9 & 4 & 2 & 5 & 11 \\
\hline
\end{tabular}

to the $30 \%$ mortality that occurred in each of the other 2 replicates.

Bacteria other than Edwardsiella ictaluri were less of a problem in the 'temperature' study than in the 'salt' study (Table 4). Aquaria with a salt content of $1000 \mathrm{mg} \mathrm{l}^{-1}$ or higher had fewer fish deaths due to mixed infections of E. ictaluri and Aeromonas sp. than aquaria with 0 and $100 \mathrm{mg}$ $1^{-1}$ salt. No Aeromonas sp. were isolated from fish in $3000 \mathrm{mg} \mathrm{l}^{-1}$ salt. At termination of the study, $10 \%$ of the survivors in 1000 $\mathrm{mg} \mathrm{l}^{-1}$ yielded E. ictaluri upon necropsy compared to $20 \%$ in the $2000 \mathrm{mg} \mathrm{l}^{-1}$ group and $0 \%$ in the $3000 \mathrm{mg} \mathrm{l}^{-1}$ group. This prevalence of $E$. ictaluri is very similar to the pre-experimental carrier level $(10 \%)$ and indicates that the prevalence of this
E. ictaluri infections. Other potentially pathogenic bacteria, such as the motile Aeromonas sp. group and Streptococcus sp., tended to occur at temperatures above and below, respectively, the optimum for clinical $E$. ictaluri infection. The time to first death due to $E$. ictaluri further supports the fact that $25^{\circ} \mathrm{C}$ is near the optimum temperature for ESC (Table 1). At $25^{\circ} \mathrm{C}$ the first $E$. ictaluri associated death occurred on Day 8 post temperature adjustment compared to Day 20 for fish held at $18^{\circ} \mathrm{C}$ and Day 16 for fish adjusted to $30^{\circ} \mathrm{C}$. The only brown blood disease problem (methemoglobinemia) occurred at $30^{\circ} \mathrm{C}$.

Although salt concentrations in our study were a fraction of that inhibiting growth of Edwardsiella ictaluri in culture media $(15000 \mathrm{mg}$ $1^{-1}$ ) (Plumb \& Vinitnantharat 1989), increased $\mathrm{NaCl}$ concentrations had a positive effect on the reduction of total cumulative mortality of channel catfish with a latent $E$. ictaluri infection (Fig. 1). Mortality was significantly greater $(p<0.05)$ in the 0 and $100 \mathrm{mg}$ $1^{-1}$ treatment groups (100 and 96\%, respectively) than in the 1000,2000 , and $3000 \mathrm{mg} \mathrm{l}^{-1}$ treatment groups (33, 43 , and $17 \%$, respectively) (Table 3 ). Salt concentrations of 1000 and 3000 mg $\mathrm{l}^{-1}$ produced mortality patterns similar to each other and were not significantly $(p>0.05)$ different, but mortality in the $3000 \mathrm{mg} \mathrm{l}^{-1}$ treatment group was significantly lower $(\mathrm{p}<$ 0.05 ) than that in the $2000 \mathrm{mg} \mathrm{I}^{-1}$ treatment group. The higher average mortality in the $2000 \mathrm{mg} \mathrm{l}^{-1}$ treatment group was due to a high $(70 \%)$ mortality in 1 of the 3 replicates compared pathogen, as well as that for the motile Aeromonas sp., did not increase in the higher salinities. At present, it is not known if the low prevalence of bacterial infection in the fish held at 1000 to $3000 \mathrm{mg} \mathrm{l}^{-1}$ salt was because the bacteria were not transmitted to non-infected fish at these salt concentrations, or if the channel catfish became more resistant due to improved osmolarity. However, Plumb \& Vinitnantharat (1989) showed that E. ictaluri grows in culture media with $10000 \mathrm{mg} \mathrm{l}^{-1} \mathrm{NaCl}$ (equivalent to $6000 \mathrm{mg} \mathrm{l}^{-1}$ chloride), suggesting that the channel catfish benefit physiologically from the salt, thus increasing resistance.

Chloride analyses carried out $24 \mathrm{~h}$ after $\mathrm{NaCl}$ was added to the aquarium water indicated that initially

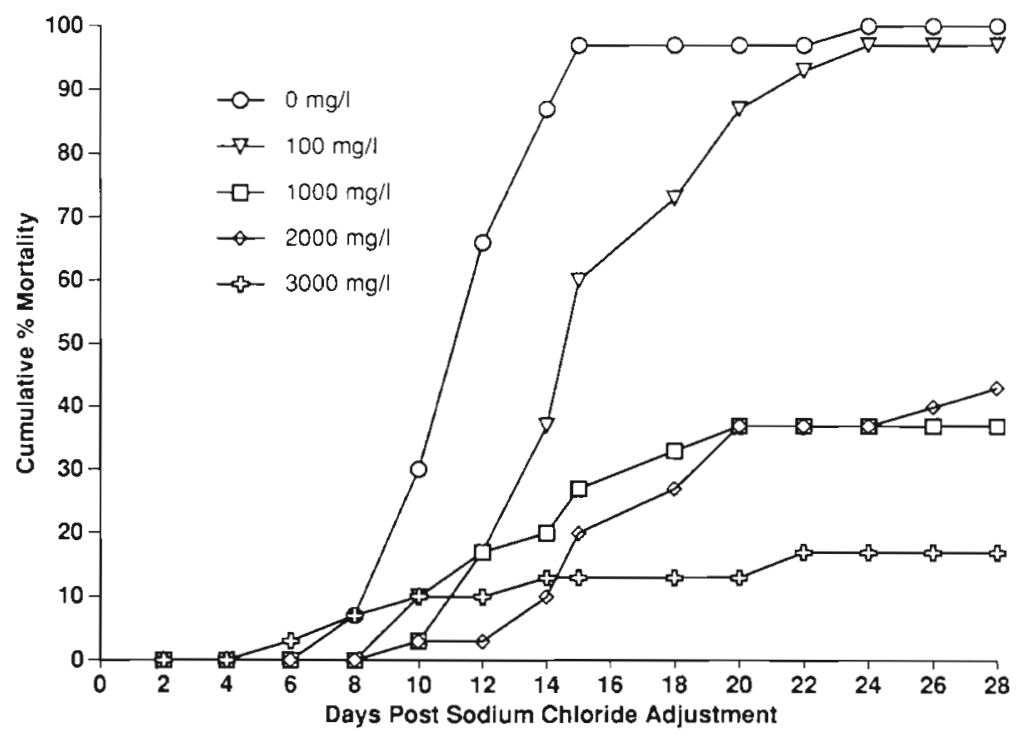

Fig. 1. Ictalurus punctatus infected with Edwardsiella ictaluri. Cumulative mortality of channel catfish naturally infected with latent bacteria and held in 0 , $100,1000,2000$, and $3000 \mathrm{mg} \mathrm{l}^{-1}$ of $\mathrm{NaCl}$ at $25^{\circ} \mathrm{C}$ for $28 \mathrm{~d}$ 
Table 3. Ictalurus punctatus infected with Edwardsiella ictaluri. Effects of increased sodium chloride concentration on mortalities (values given as \%) in latently infected channel catfish held at $25^{\circ} \mathrm{C}$ for $28 \mathrm{~d}$. Mortality values with different letters are significantly different $(p<0.05)$ from others in the same row

\begin{tabular}{|crrrrrc|}
\hline & \multicolumn{6}{c}{ NaCl concentration $\left(\mathrm{mg} \mathrm{l}^{-1}\right):$} \\
& 0 & 100 & 1000 & 2000 & 3000 \\
\hline $\begin{array}{l}\text { No. of fish stocked } \\
\text { \% mortality }\end{array}$ & 30 & 30 & 30 & 30 & 30 \\
$\begin{array}{l}\text { Total } \\
\text { Due to E. ictaluri }\end{array}$ & $100^{\mathrm{a}}$ & $96^{\mathrm{a}}$ & $33^{\mathrm{bc}}$ & $43^{\mathrm{b}}$ & $17^{\mathrm{c}}$ \\
$\begin{array}{l}\text { Day of first death due } \\
\text { to E. ictaluri }\end{array}$ & $93^{\mathrm{a}}$ & $33^{\mathrm{bc}}$ & $43^{\mathrm{b}}$ & $17^{\mathrm{c}}$ \\
\hline
\end{tabular}

chloride concentrations were near the desired level in all treatments (Table 5). At Day 28, the chloride concentrations were close to the desired level (Table 5) except in the $3000 \mathrm{mg} \mathrm{l}^{-1}$ replicates where, unfortunately, chlorides were only $877 \mathrm{mg}^{1^{-1}}$ compared to the desired concentration of near $1800 \mathrm{mg} \mathrm{l}^{-1}$. This disparity could have been due to an error in replenishing the $\mathrm{NaCl}$ during a water exchange. However, in view of the effective disease control obtained with $\mathrm{NaCl}$ at the $1000 \mathrm{mg} \mathrm{l}^{-1}$ level $\left(=600 \mathrm{mg} \mathrm{Cl}^{-} \mathrm{l}^{-1}\right)$, it may not be necessary to add $\mathrm{NaCl}$ to the $3000 \mathrm{mg} \mathrm{l}^{-1}$ level to inhibit Edwardsiella ictaluri infections.

The full benefit of adding salt to channel catfish ponds is not yet known but with few exceptions channel catfish culture is carried out in waters containing less than 200 to $400 \mathrm{mg} \mathrm{l}^{-1}$ of salinity (Boyd 1990). Although the salt content of static channel catfish ponds can be artificially increased, the initial cost of adding the required amounts per hectare would be high. However, once the salt is added to the water it

Table 4. Ictalurus punctatus. Bacteria isolated from moribund and dead channel catfish exposed to 5 concentrations of sodium chloride at $25^{\circ} \mathrm{C}$

\begin{tabular}{|c|c|c|c|c|c|}
\hline & \multicolumn{5}{|c|}{$\mathrm{NaCl}$ concentration $\left(\mathrm{mg} \mathrm{l}^{-1}\right)$ : } \\
\hline & 0 & 100 & 1000 & 2000 & 3000 \\
\hline No. of fish necropsied & 30 & 29 & 10 & 13 & 5 \\
\hline \multicolumn{6}{|l|}{ No. of fish positive for: } \\
\hline Edwardsiella ictaluri & 24 & 28 & 10 & 13 & 5 \\
\hline Aeromonas sp. & $6^{a}$ & $4^{b}$ & $1^{b}$ & $2^{b}$ & 0 \\
\hline No. of fish with no isolates & $2^{c}$ & 1 & 0 & 0 & 0 \\
\hline \multicolumn{6}{|l|}{ No. of fish positive for } \\
\hline \multicolumn{6}{|c|}{$\begin{array}{l}{ }^{a} \text { Two of six with dual infections of Aeromonas sp. and E. ictaluri } \\
{ }^{b} \text { Dual infection with Aeromonas sp. and E. ictaluri } \\
{ }^{\circ} \text { Brown blood disease suspected }\end{array}$} \\
\hline
\end{tabular}

Table 5. Ictalurus punctatus infected with Edwardsiella ictaluri. Chloride analysis of water to which sodium chloride had been added and in which infected catfish were held

\begin{tabular}{|c|c|c|c|}
\hline \multirow{3}{*}{$\begin{array}{l}\text { NaCl added } \\
\quad\left(\mathrm{mg} \mathrm{l}^{-1}\right)\end{array}$} & \multicolumn{3}{|c|}{ Chloride concentration $\left(\mathrm{mg} \mathrm{l}^{-1}\right)$} \\
\hline & \multirow[t]{2}{*}{ Theoretical $^{\mathrm{a}}$} & \multicolumn{2}{|c|}{ Measured ${ }^{\mathrm{b}}$} \\
\hline & & $24 \mathrm{~h}$ & $28 \mathrm{~d}$ \\
\hline 0 & 0 & - & 18.3 \\
\hline 100 & 60 & 66.1 & 73.1 \\
\hline 1000 & 600 & 560.3 & 588.1 \\
\hline 2000 & 1200 & 1155.0 & 1060.3 \\
\hline 3000 & 1800 & 1700.0 & 877.5 \\
\hline \multicolumn{4}{|c|}{$\begin{array}{l}{ }^{a} \text { Based on } 60 \% \text { (by weight) of } \mathrm{NaCl} \text { being chloride ions } \\
{ }^{\circ} \mathrm{Chloride} \text { ion concentration measured } 24 \mathrm{~h} \text { and } 28 \mathrm{~d} \text { after } \\
\text { addition of } \mathrm{NaCl} \text { (Boyd 1979) }\end{array}$} \\
\hline
\end{tabular}

should remain in the pond until it is drained. Furthermore, the cost of the salt would be an incentive for conserving treated water. Also, in areas where naturally high saline well water is available, $\mathrm{NaCl}$ supplements would not be as costly.

Suggested increased salinities are well within the range of channel catfish tolerance. Allen \& Avault (1969) found that salinities of $10000 \mathrm{mg} \mathrm{l}^{-1}$ of total salinity or less permitted normal growth and survival of channel catfish. The $3000 \mathrm{mg} \mathrm{1^{-1 }} \mathrm{NaCl}$ concentration, theoretically $1800 \mathrm{mg} \mathrm{l}^{-1}$ chlorides, showed the lowest total mortality $(17 \%)$ and no Edwardsiella ictaluri was isolated from fish $28 \mathrm{~d}$ after being introduced into that environment. The cost of sodium chloride treatment of ponds may be acceptable when the benefits of the treatment (increased survival of channel catfish) are considered. Mortalities of cultured channel catfish infected with $E$. ictaluri may reach $60 \%$ or more if not treated and the use of salt is particularly appealing when the cost of medication is also taken into account. One of the problems with medication is the increased incidence of $E$. ictaluri resistance to oxytetracycline and ormethoprim-sulfamethoxine (Waltman \& Shotts 1986, Plumb \& Vinitnantharat 1990). Therefore, the addition of salt to channel catfish culture ponds may be a feasible management procedure for controlling ESC.

This laboratory study was initiated to evaluate management recommendations for non-saline waters that were stimulated by actual environmental conditions. Although the study leaves some important questions unanswered the trend of reduced losses due to Edwardsiella ictaluri as a direct response to elevated salinity is clear. Experiments are now being 
designed to determine the mode of protection, lowest effective concentration, and the practicality of adding $\mathrm{NaCl}$ to channel catfish culture ponds to help prevent clinical ESC.

Acknowledgements. We thank Margaret Tanner for conducting the chloride analyses on the water samples. Support for this research was provided by the U.S. Fish and Wildlife Service contract No. FWS-141600091550-34 A, Alabama Agricultural Experiment Station Proj. No. ALA-09-011 and the Southeastern Cooperative Fish Disease Project.

\section{LITERATURE CITED}

Allen KO Jr, Avault JW Jr (1969) Effects of salinity on growth and survival of channel catfish, Ictalurus punctatus. Proc A Conf Southeast Ass Game Fish Comm 23:319-331

Austin B, Austin DA (1987) Bacterial fish pathogens: disease in farmed and wild fish. Ellis Horwood Ltd, Chichester

Blanch AR, Pinto RM, Jofre JT (1990) Isolation and characterization of an Edwardsiella sp. strain, causative agent of mortalities in sea bass (Dicentrarchus labrax). Aquaculture 88:213-222

Boyd CE (1979) Water quality in warmwater fish ponds Alabama Agricultural Experiment Station, Auburn University, Auburn

Boyd CE (1990) Water quality in ponds for aquaculture Alabama Agricultural Experiment Station, Auburn University, Auburn

Francis-Floyd R, Beleau MH, Waterstrat PR, Bowser PR (1987) Effect of water temperature on the clinical outcome of infection with Edwardsiella ictaluri in channel catfish. J Am vet med Ass 191:1413-1416

Hawke JP (1979) A bacterium associated with disease of pond

Responsible Subject Editor: T. Evelyn, Nanaimo, B.C., Canada cultured channel catfish, Ictalurus punctatus. J Fish Res Bd Can 36:1508-1512

Hawke JP, McWorter AC, Stegerwalt AG, Brenner DJ (1981) Edwardsiella ictaluri sp. nov., the causative agent of enteric septicemia of catfish. Int J Syst Bact 31:396-400

Herwig N (1979) Handbook of drugs and chemicals used in the treatment of fish diseases. Charles C. Thomas, Springfield, IL

Plumb JA (1988) Vaccination against Edwardsiella ictaluri In: Ellis A (ed) Fish vaccination. Academic Press, London. p $152-161$

Plumb JA, Vinitnantharat S (1989) Biochemical, biophysical, and serological homogeneity of Edwardsiella ictaluri. J aquat Anim Health 1:51-56

Plumb JA, Vinitnantharat S (1990) Dose titration of sarafloxicin (A-56620) against Edwardsiella ictaluri infection in channel catfish. J aquat Anim Health 2:194-197

SAS Institute Inc (1985) SAS user's guide: statistics, version 5 edn. SAS Institute, Cary, NC

Shotts EB, Bullock GL (1975) Bacterial diseases of fishes: diagnostic procedures for gram negative pathogens. J Fish Res Bd Can 32:1243-1247

Shotts EB, Waltman WD (1990) A medium for the selective isolation of Edwardsiella ictaluri. J Wildl Dis 26:214-218

Tomasso JR, Simco BA, Davis KB (1979) Chloride inhibition of nitrite induced methemoglobinemia in channel catfish (Ictalurus punctatus). J Fish Res Bd Can 36:1141-1144

Waltman WD. Shotts EB (1986) Antimicrobial susceptibility of Edwardsiella ictaluri. J Wildl Dis 22:173-177

Wellborn TL Jr (1985) Control and therapy. In: Plumb JA (ed) Principal diseases of farm raised catfish. South Coop Series Bull No 225. Alabama Agricultural Experiment Station, Auburn University, Auburn, p 50-67

Wise DJ, Schwedler TE, Otis DL (1993) Effects of stress on susceptibility of naive channel catfish in immersion challenge with Edwardsiella ictaluri. J aquat Anim Health 5 92-97

Manuscript first received: May 12, 1994

Revised version accepted: December 6, 1994 